\title{
STEREOTACTIC FIBRINOLYSIS OF SPONTANEOUS INTRACEREBRAL HEMATOMA USING INFUSION OF RECOMBINANT TISSUE PLASMINOGEN ACTIVATOR
}

\author{
José Augusto Nasser ${ }^{1 / 2}$, Asdrubal Falavigna ${ }^{1}$, Márcio Bezerra' ${ }^{1 / 2}$, Victor Martinez ${ }^{1 / 2}$, \\ Gabriel Freitas ${ }^{1 / 2}$, Armando Alaminos ${ }^{1}$, Antônio Bonatelli3, Fernando Ferraz ${ }^{3}$
}

\begin{abstract}
Purpose: The authors present a prospective study on 10 patients with stereotactic infusion of tissue plasminogen activator (rtPA) intraparenchimal hemorrhage. Methods: Between 1999 and 2000, 10 patients with deep seated hematomas in the basal ganglia were selected for stereotactic infusion of rtPA and spontaneous clot drainage. Results: All cases had about $80 \%$ reduction of the hematoma volume in the CT scan at the third day. The intracranial pressure was normalized by the third day too. There were no local or systemic complications with the use of this trombolitic. The results were shown by the Glasgow Outcome Scale with six patients in V, three in IV and one in III after 3 months. Conclusion: Early treatment and drainage with minimally invasive neurosurgery, can make these patients with deep-seated hematomas recover the consciousness and they can be rehabilitated earlier avoiding secondary complications.
\end{abstract}

KEY WORDS: hematoma lysis, recombinant tissue plasminogen activator, spontaneous intracerebral hematoma, stereotaxy.

\begin{abstract}
Fibrinólise com infusão de rtPA e drenagem estereotáxica de hematoma intracerebral espontâneo profundo

RESUMO - Objetivo: Estudo prospectivo em 10 pacientes com infusão de trombolítico (rtPA) dentro do hematoma cerebral profundo supratentorial e drenagem estereotáxica. Método: Entre 1999 e 200010 pacientes com hematomas de profundidade foram selecionados para infusão de rtPA e drenagem do coágulo espontânea. Resultado: Todos os casos obtiveram $80 \%$ de redução do volume do hematoma medidos por TC no terceiro dia. A pressão intracraniana estava normalizada no terceiro dia. Não houve complicações locais ou sistêmicas relacionadas com o uso deste trombolítico. Os resultados comparados foram mostrados pela Escala de Prognóstico de Glasgow com 6 pacientes em GrauV, 3 pacientes em Grau IV e 1 paciente em Grau III após três meses. Conclusão: Tratamento precoce e drenagem com técnica neurocirúrgica minimamente invasiva pode fazer estes pacientes terem uma recuperação da consciência mais rápida e assim serem reabilitados mais precocemente evitando complicações secundárias.
\end{abstract}

PALAVRAS-CHAVE: lise do coágulo, hematoma intracerebral, rtPA, estereotaxia.

Spontaneous intracerebral hematomas, as known as (AKA) hypertensive hemorrhages, especially those deep-seated, are still highly controversial in terms of conservative or operative therapy'. Neither nonoperative therapy nor operative management has been able to reduce the mortality or morbidity, especially since the classical neurosurgical operation for deep-seated spontaneous intracerebral hemorrhage is a high-risk procedure and controversial. Surgery is not so controversial if it is in posterior fossa, because it can promote a fast reduction in brainstem compression and produces better results. Backlund et al. and Higgins and Nashold were the first to report stereotactic evacuation of deep-seated hemorrhages ${ }^{2,3}$. They could not complete evacuation of those clots. Doi et al. and Mohadjer et al. reported their experience with urokinase infusion through a stereotactically implanted catheter inserted into the hematoma cavity ${ }^{4,5}$. Shaller et al. published the first series using tissue plasminogen activator (rtPA) through a stereotactic catheter implanted with good outcome and few complications ${ }^{6}$.

\footnotetext{
'Departamento de Neurocirurgia da Universidade Estácio de Sá, Centro de Investigação Neurológica e Instituto do Sono Estácio de Sá, Serviço de Neurocirurgia do Hospital Pró-Cardíaco - Rio de Janeiro RJ, Brasil; ${ }^{2}$ Doutorando pela Escola Paulista de Medicina - Universidade Federal de São Paulo SP, Brasil (EPM - UNIFESP); ${ }^{3}$ Professor Adjunto de Neurocirurgia da EPM-UNIFESP.
}

Received 21 September 2001, received in final form 12 December 2001. Accepted 7 January 2002.

Dr. José Augusto Nasser - Avenida Ataulfo de Paiva, 1079/1001 - 22440-031 Rio de Janeiro RJ - Brasil - www.estacio.br/ines FAX: 212294 5329. E-mail: nasser@riodejaneiro.net 
This prospective study analyzes the efficacy and safety of clot lysis with rtPA stereotactically infused and spontaneous drainage of hypertensive deep intracerebral hematoma. Results are compared with control group and the literature is reviewed.

\section{METHOD}

\section{Patient population}

Between November 1999 and October 2000 at the emergency room (ER) of Pró-Cardíaco Hospital, 10 patients with hypertensive spontaneous basal ganglia hematomas were selected among 24 patients with deep intracerebral hematomas. The mean age was 66.4 years (ranging 61 74 years) being six males. Six patients were considered control group. They were not considered surgical candidates because even having hypertensive basal ganglia hematomas they presented one of exclusion items described below.

Informed consent for therapy, approved by PróCardíaco Hospital ethical committee, was obtained from the patients and/or their relatives.

\section{Inclusion and exclusion criteria}

Patients were selected based on: a) an impairment of consciousness level; b) no signs of herniation (midbrain symptoms, wide and fixed pupil); c) hematoma volume more than $30 \mathrm{cc}$; d) less than $48 \mathrm{hs}$ of onset; e) no arteriovenous malformation (AVM) in digital angiography suspected ; f) no evidence of systemic bleeding disease; g) Glasgow coma scale (GCS) score not less than 5; e) complete routine laboratory study negative for blood dyscrasias, coagulopathies, drug tests, infection and erythrocyte sedimentation rate as evidence for vasculitis.

\section{Radiological procedures}

CT scan was performed in all patients less than 3 hours of admission. The diameter and thickness of the hematoma was assessed. Patients whom a vascular malformation was suspected, an angiography was performed before the hematoma lysis.

\section{Operative technique}

The stereotactic arc was fixed under local anesthesia. A stereotomography was performed. Those images were transferred to the workstation. At the workstation using the MSPS software (A. Alaminos - Micromar - São Paulo SP - Brazil) the coordinates for the hematoma center were acquired. This isocenter was used as our target to insert the silicone hematoma drainage catheter (Nasser AntiBlock Catheter - Phoenix - Valley Forge - PA- USA) especially designed to this protocol. At the same time the coordinates of the lateral ventricle were acquired in order to insert a silicone ventricular drainage catheter and monitor the intracranial pressure (ICP) and had cerebrospinal fluid (CSF) drainage in the presence of intracranial hypertension. In the operating room, under local anesthesia those two catheters were implanted using the ETM-03B Stereotactic System (Micromar - São Paulo SP - Brazil), and fixed at the skull. Both catheters were connected individually with an external closed drainage system. Back to the neuroradiological suite, a new CT scan was done to check the correct position of those catheters. The patients were transferred to the Neuro ICU.

\section{Hematoma lysis protocol}

RtPA (Actilyse - Boehringer llgelheim - Brazil) infusion was calculated under Schaller's protocol, one milligram of rt-PA equaled a volume of one milliliter ${ }^{6}$. It is based on the data from Lippitz and Shaller showing this volume is effective and low toxicity ${ }^{6}$. If the maximum diameter of the hematoma was $5 \mathrm{~cm}$, then $5 \mathrm{mg}$ of rtPA was administered. The system was closed for 2 hours and then opened through a closed drainage system against $0 \mathrm{~cm}$ of pressure. The authors did not use hematoma evacuators. The drainage was kept spontaneous.

CT scan was performed after 24 hours to re-evaluate the hematoma size and calculate the second rtPA dose. The catheters were left in place for an additional 48 hours to drain the residual blood. The ventricular catheter was removed after 24 hours of normal intracranial pressure.

\section{Follow up}

The results were graded according to the Glaslow Outcome Scale (GOS) ; GOS V, good recovery, GOS IV, moderate disability (independent); GOS III, severe disability (dependent on others); GOS II, vegetative state; GOS I, dead'. Also a neurologic exam was done to compare the neurological deficits before and after the procedure in long term.

\section{RESULTS}

Table 1 shows 10 patients, admitted at the ER of Pró-Cardíaco Hospital. The maximum diameter of those hematomas varied from 4 to $6 \mathrm{~cm}$. All those patients had deep seated hematomas, being 5 thalamic ( 3 right and 2 left) and 5 putaminal (3 right and 2 left). Two patients in whom the history of systemic arterial hypertension was not clear before, both thalamic underwent subtraction digital angiography which were both normal.

At the admission the level of consciousness was related to the hematoma size and location. Five patients were in GCS less than 8. Seven were hemiparetic and among them, 4 were hypertonic.

Six patients presented ventricular clot. Three had acute hydrocephalus. None needed permanent shunt. The ventricular drainage system was programmed to open and drain only if the intracranial pressure becomes higher than $20 \mathrm{mmHg}$. Otherwise it worked as a monitoring device. These 3 patients with acute hydrocephalus the ventricular drainage volume in each 5 early days exceeded $200 \mathrm{ml} /$ day , 
but after 5 days this volume decreased and after 7 days the volume and the pressure were normalized .

Every patient had a second dose of rt-PA calculated same way the first. None had a third dose. At the third day, CT scan showed in all patients reduction of $80 \%$ hematoma volume and less perilesional edema (Fig 1). The hematoma catheter was left in place for an additional 48 hours to drain the residual blood. The volume drained was ranged from 80 to $180 \mathrm{ml}$ of liquefied clot, depending on the hematoma's volume.

The ventricular catheter was removed after 24 hours of normal intracranial pressure, usually at the fifth day and with the aspect of the CSF clear.

Six patients presented fast improvement in their consciousness, in 48 hours (Fig 2). It was less evident to observe it in patients with left thalamic clots.

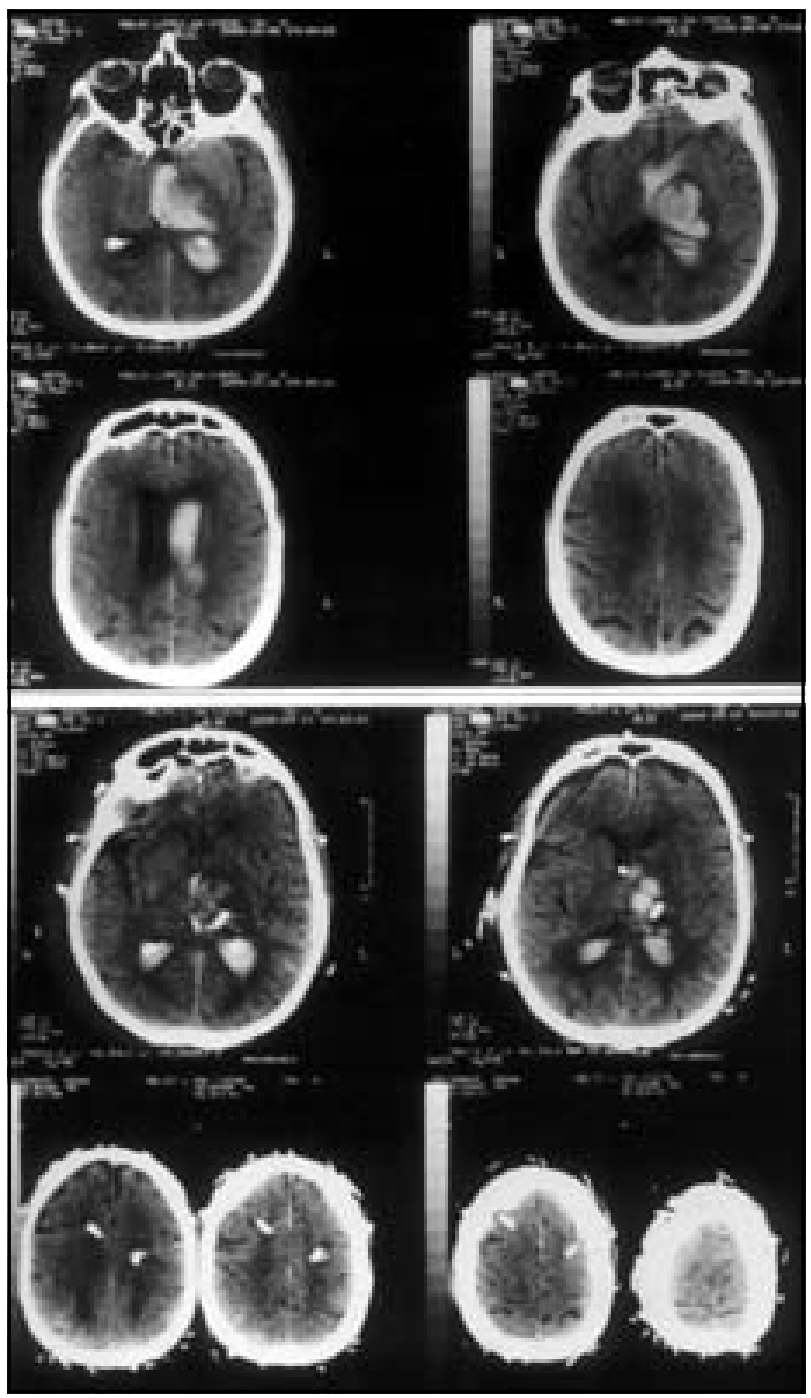

Fig 1. Patient 5. Seventy four -year-old man with left hypertensive thalamic hematoma and intraventricular clot. A, CT at admission. $B, C T$ on day 3 showing significant reduction of the hematoma.
Two patients with left thalamic clot, one right thalamic and one left putaminal had less improvement in consciousness level.

The mean hospitalization's time was 15 days. Two patients who stayed longer had left thalamic hematoma. There were no dead in this series and no side effects related with rtPA.

The mean follow up evaluation at 3 months shows that 6 patients are now in GOS V, 3 patients are in GOS IV and only one is in GOS III. This patient had a left thalamic hematoma, his GCS score at the admission was 6 , and was hemiplegic. He is still hemiplegic even after 4 months of rehabilitation. Two out 3 in GOS 4 had hemiplegia at the admission and now they improved to grade 3 and 4 in muscle

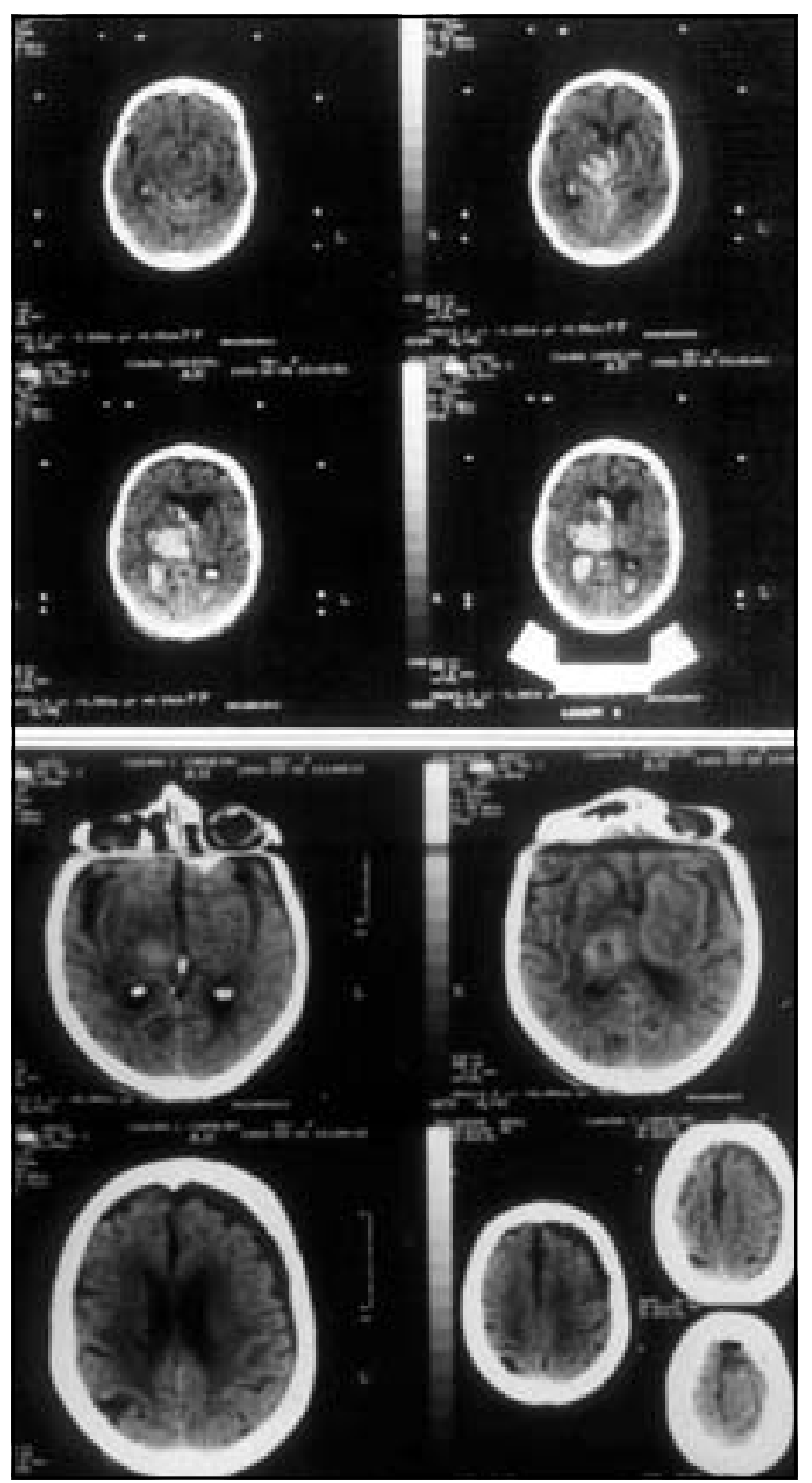

Fig 2. Patient 9: Seventy two-year-old woman with right thalamic hematoma and intraventricular clot. A, CT at admission. B, on day 8 with complete reabsorption of the clot. 
Table 1. Clinical data and octcome of 10 patients with spontaneous basal ganglia hematomas.

\begin{tabular}{ccccccc}
\hline Patient & Sex & $\begin{array}{c}\text { Age } \\
\text { (years) }\end{array}$ & $\begin{array}{c}\text { Hematoma size } \\
\text { (diameter in cm) }\end{array}$ & Localization & $\begin{array}{c}\text { Glasgow coma } \\
\text { scale admission }\end{array}$ & $\begin{array}{c}\text { Glasgow } \\
\text { outcome scale* }\end{array}$ \\
\hline 1 & $\mathrm{M}$ & 70 & 5 & L Putamen & 9 & $\mathrm{~V}$ \\
2 & $\mathrm{M}$ & 64 & 5 & L Thalamus & 6 & $\mathrm{III}$ \\
3 & $\mathrm{~F}$ & 62 & 4 & R Putamen & 9 & $\mathrm{~V}$ \\
4 & $\mathrm{~F}$ & 68 & 6 & R Putamen & 6 & $\mathrm{~V}$ \\
5 & $\mathrm{M}$ & 74 & 4 & L Thalamus & 6 & $\mathrm{IV}$ \\
6 & $\mathrm{~F}$ & 68 & 4 & R Thalamus & 7 & $\mathrm{IV}$ \\
7 & $\mathrm{M}$ & 61 & 5 & R Putamen & 9 & $\mathrm{~V}$ \\
8 & $\mathrm{M}$ & 62 & 5 & L Putamen & 7 & $\mathrm{~V}$ \\
9 & $\mathrm{~F}$ & 72 & 5 & R Thalamus & 6 & $\mathrm{~V}$ \\
10 & $\mathrm{M}$ & 69 & 4 & R Thalamus & 8 & $\mathrm{IV}$ \\
\hline
\end{tabular}

Data Bank from Department of Neurosurgery, Pró-Cardiaco Hospital - Rio de Janeiro - RJ - Brasil.

Glasgow outcome scale (GOS): GOS V (good recovery); Gos IV (moderate disability); GOS III (severe disability - dependent of others); GOS II (vegetative state); GOS I (dead). *GOS after 3 months.

strength scale. Those patients are constantly being followed by our rehabilitation service.

It is important to mention that all these patients were admitted in the first 6 hours after ictus. It was observed enlargement of the hematoma from the first $\mathrm{CT}$ until the stereo $\mathrm{CT}$ in two thalamic hematomas.

No side effects were observed with this protocol of rtPA in terms of toxicity or hematoma enlargment. All patients had some improvement regarding GOS or neurologic examination

Comparing those surgical patients with control group (non surgical) it was found: a) mean 10 days less of hospitalization; b) 3 days of recovering of consciousness state on surgical against 10 days on non-surgical; c) morbidity was $25 \%$ higher on control group; d) mortality was 0 on surgical group compared to $30 \%$ on control group caused by intracranial hypertension; e) secondary complications were $40 \%$ more on control group; f) hospitalization costs were two times higher on control group; g) GOS was predominantly III on control group and IV on surgical.

\section{DISCUSSION}

After experimental studies and clinical trials showed the efficacy and safety of the rtPA instillation in subarachnoid hemorrhage, lysing the clots, some authors based on previous experience with urokinase infusion, started to think about clot lysis with rtPA ${ }^{8-12}$.
The prognosis of thalamic hemorrhage has a close correlation with hematoma size and ventricular extension of hemorrhage. Chung et al. demonstrated that the mortality was $81 \%$ when thalamic hemorrhage presented the entire area of the thalamus: global type ${ }^{13}$. The volume of ventricular blood is an important determinant of outcome in supratentorial intracerebral hemorrhage, as shown by Tuhrim et al. ${ }^{14}$.

Reabsorption of hematoma with good neurological outcome was observed following stereotactic infusion of rt-PA for clot lysis and drainage in all those cases except one in the left thalamus, however on control group the results were less impressive.

The authors share the idea of Schaller et al., regarding pure fibrinolytic trial with careful drainage instead of forceful hematoma aspiration preventing secondary bleeding ${ }^{6,15}$. There is a clear benefit using rtPA over urokinase. There have been some reports regarding the neurotoxity of urokinase and new bleeding related to urokinase overdose ${ }^{16,17}$. The risk of using rtPA infusion inside the hematomas is rebleeding . It has been published, but the right selection of those patients, with careful investigation of bleeding diseases can be useful to prevent $i^{18}$.

These patients had a good outcome: $60 \%$ (GOS V) , $30 \%$ (GOS IV) and 10\% (GOS III), after 3 months follow-up.

The whole procedure was completed in 3 hours. 
We know from the literature that during the early period after the ictus, intracerebral hematomas may cause neurological deterioration as a result of an increasing mass effect caused by surrounding edema, and this can last up to 4 weeks ${ }^{19,20}$. The good outcome in these patients could be explained due the fact that admission and diagnosis took about 4 hours. Also it seems that in eloquent areas, some deficits are related with the ischemic caused by the mass effect of the hematoma in the surround areas.

These results suggest that this procedure is safe, effective on selected patients. Early treatment and evacuation, with stereotactic minimally invasive neurosurgery, could make these patients, with deepseated hematomas, have a recovery of the consciousness state and this way they could be rehabilitated soon, helping them having less secondary complications.

\section{REFERENCES}

1. Schwarz S, Jauss M, Krieger D, Dorfler A, Albert F, Hacke W. Haematoma evacuation does not improve outcome in spontaneous supratentorial intracerebral hemorrhage: a case-control study. Acta Neurochir (Wien) 1997;139:897-904.

2. Backlund E, van Hoslt M. Controlled subtotal evacuation of intracerebral hematomas by stereotactic technique. Surg Neurol 1978;9:99-101.

3. Higgins AC, Nashold BS. Stereotactic evacuation of large intracerebral haematomas. Appl Neurophysiol 1980;43:96-103.

4. Doi E, Moriwaki M, Komai N, Iwamoto M. Stereotactic evacuation of intracerebral hematomas. Neurol Med Chir (Tokyo) 1982;22:461-467.

5. Mohadjer M, Braus DF, Myers A, Scheremet R, Krauss JK. CT-stereotactic fibrinolysis of spontaneous intracerebral hematomas. Neurosurg Rev 1992;15:105-110.
6. Schaller C, Rohde V, Meyer B, Hassler W. Stereotactic puncture and lysis of spontaneous intracerebral hemorrhage using recombinant tissue-plasminogen activator. Neurosurgery 1995;36:328-335.

7. Jennett B, Bond M. Assessment of outcome after severe brain damage: a practical scale. Lancet 1975;I:480-484.

8. Deinsberger W, Vogel J, Fuchs C, Auer LM, Kuschinsky W, Boker DK. Fibrinolysis and aspiration of experimental intracerebral hematoma reduces the volume of ischemic brain in rats. Neurol Res 1999;21:517523.

9. Grabb PA. Traumatic intraventricular hemorrhage treated with intraventricular recombinant -tissue plasminogen activator: technical case report. Neurosurgery 1998;43:966-969.

10. Kim MH, Kim EY, Song JH, Shin KM. Surgical options of hypertensive intracerebral hematoma: stereotactic endoscopic removal versus stereotactic catheter drainage. J Korean Med Sci 1998;13:533-540.

11. Lippitz BE, Mayfrank L, Spetzger U, Warnke JP, Bertalanffy H, Gilsbach JM. Lysis of basal ganglia haematoma with recombinant tissue plasminogen activator (rtPA) after stereotactic aspiration: initial results. Acta Neurochir (Wien) 1994;127:157-160.

12. Mayfrank L, Lippitz B, Groth M, Bertalanffy H, Gilsbach JM. Effect of recombinant tissue plasminogen activator on clot lysis and ventricular dilatation in the treatment of severe intraventricular hemorrhage. Acta Neurochir (Wien) 1993;122:32-38.

13. Chung CS, Caplan LR, Han W, Pessin MS, Lee KH, Kim JM. Thalamic hemorrhage. Brain 1996;119:1873-1886.

14. Thurim S, Horowitz D, Sacher M, Godbold J. Volume of ventricular blood is an important determinant of outcome in supratentorial intracerebral hemorrhage. Critical Care Med 1999;27:617-621.

15. Amano K, Kawamura H, Tanikawa T, et al.. Surgical treatment of hypertensive intracerebral haematoma by CT-guided stereotactic surgery. Acta Neurochir (Wien) 1987;39(Suppl):41-44.

16. Masuda T, Dorhmann GJ, Kwaan HC, Erickson RK, Wollman RL. Fibrinolytic activity in experimental intracerebral hematoma. J Neurosurg 1988;68:274-278.

17. Yague L, Garcia-March G, Paniagua C, et al. Stereotactic evacuation and local administration in intracerebral haematomas: a comparative study. Acta Neurochir (Wien) 1987;39(Suppl):45-48.

18. Whitelaw A, Saliba E, Fellman V, Mowinckel MC, Acolet D, Marlow N. Phase I study of intraventricular recombinant tissue plasminogen activator for treatment of posthaemorrhagic hydrocephalus. Ach Dis Child Fetal Neonatal 1996;75:20-26.

19. Altumbabic M, Peeling J, Del Biggio MR. Intracerebral hemorrhage in the rat: effects of hematoma aspiration. Stroke 1998;29:1917-1922.

20. Zazulia AR, Diringer MN, Derdeyn CP, Powers WJ. Progression of mass effect after intracerebral hemorrhage. Stroke 1999;30:1167-1173. 